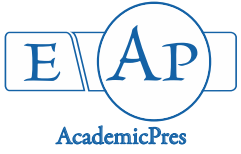

Oloyede HOB et al. (2020)

Notulae Scientia Biologicae 12(3):556-567

DOI: $10.15835 / \mathrm{nsb} 12310629$

Research Article

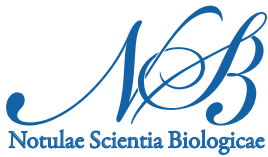

\title{
Protective potentials of ethyl acetate-ethanolic fraction of Carica papaya leaves against acetaminophen-induced liver damage in rats
}

\author{
Hussein O.B. OLOYEDE, Halima Y. LUKMAN, Musa O. SALAWU* \\ University of Ilorin, Faculty of Life Sciences, Department of Biochemistry, Ilorin, Kwara State, Nigeria; oboloyede@unilorin.edu.ng; \\ halimatyusuf40@gmail.com; salawu.mo@unilorin.edu.ng(*corresponding author)
}

\begin{abstract}
The liver is an important organ performing vital roles that become affected when damaged. The protective potential of ethyl acetate-ethanolic fraction of Carica papayaleaves on acetaminophen-induced liver damage in female albino rats was investigated. Forty female rats were completely randomized into eight groups (A-H) of five rats each. Group A (control), received $1 \mathrm{ml}$ of distilled water, group B (untreated) received 250 mgkg ${ }^{-1}$ bw of acetaminophen, group $C$ received silymarin $\left(50 \mathrm{mgkg}^{-1} \mathrm{bw}\right)$ followed by actaminophen (250 $\mathrm{mgkg}^{-1} \mathrm{bw}$ ), groups D-G received 100, 200, 400 and $600 \mathrm{mgkg}^{-1}$ bw of ethyl acetate-ethanolic fraction of Carica papaya leaves respectively; followed by acetaminophen administration $\left(250 \mathrm{mgkg}^{-1} \mathrm{bw}\right)$, while group $\mathrm{H}$ (toxicity control) received $600 \mathrm{mgkg}^{-1}$ bw extract fraction daily. Ethyl acetate-ethanolic fraction of Carica papaya leaves significantly $(\mathrm{p}<0.05)$ decreased the activities of alanine aminotransferase, aspartate aminotransferase, alkaline phosphatase, gamma glutamyl transferase and bilirubin concentration and increased the concentrations of total protein and albumin in acetaminophen-induced liver damaged rats when compared with the untreated group. Prevention of liver damage was observed in the groups pre-administered 400 and $600 \mathrm{mgkg}^{-1} \mathrm{bw}$ of the extract fraction as well as the silymarin group. Activities of superoxide dismutase and catalase and the concentration of glutathione were significantly $(\mathrm{p}<0.05)$ increased while the concentration of malondialdehyde was significantly $(\mathrm{p}<0.05)$ decreased in rats pre-administered with silymarin or the extract fraction when compared with the acetaminophen-induced rats. Ethyl acetate-ethanolic fraction of Carica papaya leaves prevented acetaminophen-induced rat liver damage probably mainly due to the antioxidant constituents of the fraction.
\end{abstract}

Keywords: acetaminophen-induced liver damage; antioxidant; Carica papaya; ethyl acetate-ethanol fraction; flavonoids

\section{Introduction}

Liver is the largest internal organ of the human body; it performs vital metabolic functions such as biotransformation and detoxification of many endogenous and exogenous compounds. Numerous xenobiotics are metabolized by the mixed functions of monooxidases found in hepatocytes via oxidation, reduction, hydration, hydrolysis, condensation, conjugation, or isomerization Ozougwu et al. (2017). Interruption of 
these processes can lead to hepatotoxicity, causing liver cancer, cirrhosis and Hepatitis C, respectively. Such diseases are responsible for higher mortality rates worldwide. The global burden of hepatotoxicity affects over fifty million people worldwide making it a highly fatal disease (Chavan, and Kuvalekar, 2019).

Liver damage is caused by hepatotoxins, which may source from chemicals, dietary supplements, pharmaceutical drugs, and medicinal plants. Acetaminophen is an analgesic which when overdosed produces a reactive intermediate in large amounts that affects the functionality of the liver. Acetaminophen is the most used over-the-counter analgesic; it is safe when consumed in limited doses, though safety is narrow. When it is overdosed, series of reaction that produces reactive intermediate occur. This can result in severe liver damage and subsequently acute liver damage. Patients with acetaminophen-induced acute liver failure may recover when proper managed or results in death if otherwise (Atallah Albalawi et al., 2019).

Notably, numerous medicinal plants are used to alleviate illness, particularly in traditional systems of medicine, such as Ayurveda and Traditional Chinese Medicine. These systems of medicine have been implemented for centuries for treating various ailments. Some medicinal plants serve as hepatoprotectors against liver damage, while others induce hepatotoxicity. Plants such as Silybum marianum, Andrographis lineate, Phyllanthus amarus contain compounds that confer hepatoprotection (Thompson et al., 2017).

In Nigeria, several plants have been used in the management of liver diseases; among them is Carica papaya (pawpaw). C. papaya Linn; (family: Caricaceae) is an important fruit tree that possesses nutritional and health benefits. The leaves of pawpaw have been shown to contain many active components that can increase the total antioxidant power in blood and reduce lipid peroxidation level, such as papain, chymopapain, cystatin, tocopherol, ascorbic acid, flavonoids, cyanogenic glycosides and glucosinolates (Otsuki et al., 2009). The leaves of Carica papaya are used locally for the treatment of fever, pyrexia, diabetes, gonorrhoea, syphilis, inflammation and as dressing for wounds (Adeneye and Olagunju, 2009). Some of the scientifically validated uses of C. papaya include anti-ulcerogenic (Oloyede et al., 2015), hepatoprotective (Saleem and Naseer, 2014). However, there is limited information on the use of mixture of solvents capable of producing a high amount of polyphenol from Carica papaya. Therefore, this contributed to the desire to undertake this study.

\section{Materials and Methods}

\section{Materials}

Plant material

The C. papaya leaves were collected within the Kwara State General Hospital Ilorin, Kwara state, Nigeria. The plant was identified and authenticated at the Herbarium unit of the Department of Plant Biology, University of Ilorin with the voucher number UIH001/0971.

Experimental animals

Forty healthy female albino rats (Wistar strain) weighing $150 \pm 4.54 \mathrm{~g}$ were obtained from the animal house of the Department of Biochemistry, University of Ilorin, Kwara State, Nigeria. They were kept in the laboratory for 2 weeks before the commencement of the experiment at ambient temperatures and natural daylight and night time periods.

Chemicals and reagents

All chemicals and reagents used for this research were of analytical grade and assay kits were products of Randox Laboratories Co-Artrim, United Kingdom. 5,5'-Dithiobis-(-2-Nitrobenzoic acid) (DTNB), Thiobarbituric acid (TBA,) Epinephrine, Sulphosalicylic acid, Trichloroacetic acid (TCA), product of SigmaAldrich Inc., St. Loius, USA. 


\section{Methods}

\section{Preparation of extract}

The method described by Liu (2004), was used for extract preparation with slight modification.

The plant was washed and air dried for 2 weeks and later oven dried at $40{ }^{\circ} \mathrm{C}$ for 1 hour to obtain a constant dried content and milled to fine powder. $1000 \mathrm{~g}$ of plant powder was soaked in $70 \%$ ethanol for 48 hours, filtered and concentrated under reduced pressure. The concentrated extract was defatted with petroleum ether for 24 hours in a separating funnel and the lipid layer was decanted and petroleum ether was allowed to evaporate off the residue.

Extract fractionation of the extract was carried out with ethanol and ethyl acetate (Mabry et al. 1975; Cai et al., 2010). The defatted residue was subjected to column chromatography. The column was packed with silica gel (60-120 $\mathrm{mm}$ pore size) and allowed to equilibrate for few minutes before the extract was layered on top and washed through with the solvent.

\section{Solvent ratio variation}

$\mathrm{N}$-hexane and ethyl acetate were used for extract fractionation at different ratios. The extract fractions obtained were analyzed for the presence of flavonoid. Ethanol and ethyl acetate extract fractions were obtained at ethanol: ethyl acetate ratio of 1:4 (v/v) was used. The extract fractions were analyzed for the presence of flavonoid. The extract fractions that tested positive were concentrated to yield a viscous concentrate of more than $25 \mathrm{~g}$.

\section{Thin layer chromatography (TLC)}

The method described by Markham (1975) was employed. The sample was analyzed by TLC using silica gel G60 plates developed with benzene: acetic acid: water (125:72:3). Brief exposure of the plate to iodine vapour produced yellow to brown spots against the white background after development (Figure 1).

\section{Phytochemical analysis of ethyl acetate-ethanolic fraction of Carica papayaleaves}

Chemicals tests were carried out on the extract fraction using standard procedure to identify the constituents as described by Odebiyi and Sofowora (1978), Sofowora (1993), Trease and Evans (1989) and Harbone (1973) and the constituents were quantified.

\section{Experimental design}

Forty female rats were randomly distributed into 8 groups of 5 rats each. Group A served as normal control group that received the vehicle, distilled water $\left(1 \mathrm{mlkg}^{-1}\right.$ body weight). Group B served as the acetaminophen-induced group which received $250 \mathrm{mgkg}^{-1}$ bw of acetaminophen. Group C was preadministered with $50 \mathrm{mgkg}^{-1}$ bw of silymarin while groups D, E, F and G were given ethyl acetate-ethanolic fraction of $C$. papaya leaves at doses of 100, 200, 400 and $600 \mathrm{mgkg}^{-1}$ bw, respectively. Group H served as the toxicity group that received $600 \mathrm{mgkg}^{-1} \mathrm{bw}$ of extract fraction. Mode of administration for groups $\mathrm{C}-\mathrm{G}$ was adopted from Ali et al. (2013), which was pre-administration of the extract fraction or drug for treatment, followed by administration of hepatotoxicant (acetaminophen) 3 hours later for two weeks. Extract fraction was standardized in $10 \% \mathrm{w} / \mathrm{v}$ distilled water and appropriately diluted for administration.

\section{Collection of serum and homogenate preparation}

The animals were sacrificed under diethyl ether anesthesia; the jugular veins were exposed and cut with a sharp surgical blade. The blood was allowed to clot for about 15 minutes and centrifuged at $3000 \mathrm{rpm}$ for 10 minutes. Serum was collected with a Pasteur pipette and stored frozen. The liver was carefully excised and preserved in $10 \%$ buffered formaldehyde solution for histopathology. Liver homogenate was prepared by homogenizing liver in $0.25 \mathrm{M}$ cold sucrose solution and centrifuged at $4000 \mathrm{rpm}$ for 10 minutes. The supernatant collected was stored for further use (Yakubu et al., 2006). 

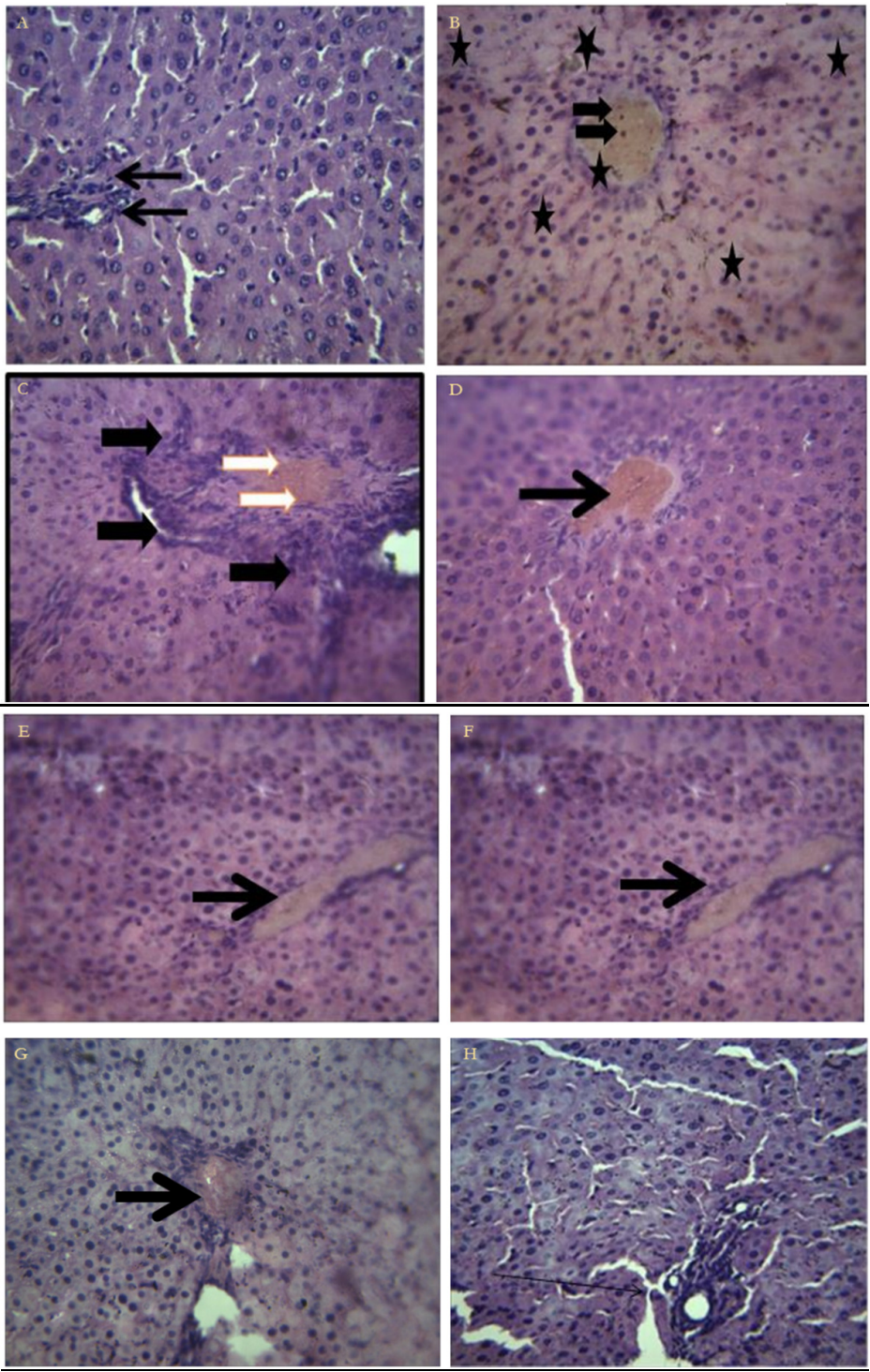

Figure 1. Cross section of liver A) Cross section of liver of that received $1 \mathrm{~mL}$ of distilled water (X400, $\mathrm{H} \& \mathrm{E}$ ). Arrows show very mild periportal cellular infiltration by mononuclear cells though the hepatocytes; B) Cross section of liver ofacetaminophen-induced rat (X400, $\mathrm{H} \& \mathrm{E})$. There was a mild diffuse hydropic degeneration of hepatocytes (stars), with mild periportal cellular infiltration (arrows) and visible lesions; C) Cross section of liver of acetaminophen-induced rat pre-administered $1 \mathrm{~mL}$ of $50 \mathrm{mg} / \mathrm{kg}$ body weight of silymarin (X400, H \& E). There was a mild congestion of the portal vessels (white arrows), with mild periportal cellular infiltration by mononuclear cells (black arrows); D) Cross section of liver of acetaminophen-induced rat pre-administered $1 \mathrm{~mL}$ of $100 \mathrm{mg} / \mathrm{kg}$ body weight of fraction of $C$. papaya leaves $(\mathrm{X} 400, \mathrm{H} \& \mathrm{E})$. Arrow shows mild congestion of the portal vessels with lesion. The hepatocytes showed visible lesions; E) Cross section of liver of acetaminophen-induced rat pre-administered $1 \mathrm{~mL}$ of $200 \mathrm{mg} / \mathrm{kg}$ body weight of fraction of C. papaya leaves (X400, H \& E). Arrow shows visible lesions. There were normal arrangements of hepatocytes with visible lesions; F) Cross section of liver of acetaminophen-induced rat preadministered $1 \mathrm{~mL}$ of $400 \mathrm{mg} / \mathrm{kg}$ body weight of fraction of C. papaya leaves (X400, H \& E). Arrow shows visible lesions. There were normal arrangements of hepatocytes with visible lesions; G) Cross section of liver ofacetaminophen-induced rat pre-administered $1 \mathrm{~mL}$ of $600 \mathrm{mg} / \mathrm{kg}$ body weight of fraction of C. papayaleaves (X 400 , $H \&$ E). Arrow shows visible lesions. Very mild periportal cellular infiltrations by mononuclear cells were visible though the hepatocytes were normal; $H$ ) Cross section of liver of rat administered $1 \mathrm{~mL}$ of $600 \mathrm{mg} / \mathrm{kg}$ body weight of fraction of C. papaya leaves (X400, H \& E). Arrow shows very mild lesions with no hepatocyte degeneration. There was very mild periportal cellular infiltration by mononuclear cells 
Determination of liver to body weight ratio

The liver to body weight ratio expressed in percentage was determined according to the mathematical expression below (Yakubu et al., 2006):

(Fresh weight of liver/ weight of animal) $\times 100$

Biochemical assays

The sera were assayed for the liver enzymes; alanine aminotransferase (ALT), aspartate aminotransferase (AST) by method of Reitman and Frankel (1957), alkaline phosphate (ALP) and $\gamma$-glutamyltransferase (GGT) by method of Rec (1972) and Teitz (1987) respectively, total protein by method of Gornall et al. (1949) and albumin (Grant et al., 1987) using standard diagnostic test kits (Randox Laboratories, Crumlin, U.K.)

Superoxide dismutase (SOD)

The activity of SOD in liver of rats was determined as described by Misra and Fridovich (1972). Briefly, $0.2 \mathrm{~mL}$ of homogenate was added to $2.5 \mathrm{~mL}$ of $0.05 \mathrm{molL}^{-1}$ carbonate buffer $(\mathrm{pH} 10.2)$ to equilibrate and the reaction was started by addition of $0.3 \mathrm{~mL}$ of freshly prepared $0.3 \mathrm{mmolL}^{-1}$ epinephrine. An increase in absorbance was recorded at $480 \mathrm{~nm}$ every $30 \mathrm{~s}$ for $150 \mathrm{~s}$. One unit of enzyme activity is $50 \%$ inhibition of the rate of auto-oxidation of epinephrine as determined by change in absorbance $/ \mathrm{min}$ at $420 \mathrm{~nm}$.

Catalase (CAT)

The activity of CAT in liver of rats was determined as described by Sinha (1972). Briefly, $1 \mathrm{ml}$ of 0.01 $\mathrm{M}$ phosphate buffer ( $\mathrm{pH} 7.0$ ) was added to $0.4 \mathrm{ml}$ of $\mathrm{H}_{2} \mathrm{O}_{2}(0.2 \mathrm{M})$ followed by $0.1 \mathrm{ml}$ of sample and gently swirled at room temperature. The reaction mixture was stopped by the addition of $2 \mathrm{ml}$ of dichromate acetic acid reagent ( $5 \%$ of dichromate prepared in acetic acid). The changes in the absorbance was measured at 620 $\mathrm{nm}$ and recorded after 3 minutes interval.

\section{Reduced glutathione (GSH)}

The level of GSH in the homogenate was determined using the procedure described by Ellman (1959). Homogenate $(1.0 \mathrm{ml})$ was added to $0.1 \mathrm{ml}$ of $25 \%$ TCA and precipitate was removed by centrifuge at $5000 \times$ $\mathrm{g}$ for $10 \mathrm{~min}$. Supernatant $(0.1 \mathrm{~mL})$ was added to $2 \mathrm{ml}$ of $0.6 \mathrm{mmol} / \mathrm{L}$ DTNB prepared in $0.2 \mathrm{~mol} / \mathrm{L}$ sodium phosphate buffer ( $\mathrm{pH} 8.0)$. The absorbance was read at $412 \mathrm{~nm}$.

\section{Malondialdehyde}

A portion of thiobarbituric acid $(2 \mathrm{ml})$ and $1 \mathrm{ml}$ of trichloroacetic acid were added to $2 \mathrm{ml}$ of the sample. The mixture was thoroughly heated in a water bath at $100^{\circ} \mathrm{C}$ for 20 minutes. It was then cooled and centrifuged at $4000 \mathrm{rpm}$ for 10 minutes. The absorbance of the supernatant was read at a wavelength of $540 \mathrm{~nm}$ against a reference blank of distilled water.

\section{Histology}

The rat livers were carefully dissected out and rinsed in normal saline. The liver tissue sections obtained were fixed in $10 \%$ formalin solution. They were then processed into $5 \mu \mathrm{m}$ thick sections stained with hematoxylin-eosin and observed under a photomicroscope ( $400 \mathrm{x})$.

\section{Statistical analysis}

Results were expressed as the mean \pm SEM of four determinations. The data were also analyzed using one-way ANOVA and the differences were considered statistically at a significance of $(\mathrm{P}<0.05)$ using Duncan Multiple Range Test. All the analysis was done using SPSS version 21.0 software (SPSS Inc., Chicago, IL, USA). 


\section{Results}

\section{Thin layer chromatography and phytochemical analysis}

Crude extraction of phytochemicals from Carica papaya leaves produced different coloured extract fractions when various solvent ratios was used. The phytochemical screening of these extract fractions revealed the presence of several phytochemicals with flavonoids constituting the highest amount (Table 1). Ethyl acetate-ethanolic fraction of Carica papayaleaves (EEFCPL) moved in line with the standard (quercetin) used though at a lowered rate (Figure 2) which means another type of flavonoid and not quercetin is contained in the extract fraction.

The liver to body weight ratio of acetaminophen-induced rats pre-administered with EEFCPL showed no significant $(\mathrm{P}>0.05)$ difference when compared with the control (non-induced), acetaminophen-induced, silymarin pre-administered or toxicity group (Table 2). Ethyl acetate-ethanolic of Carica papaya leaves significantly $(\mathrm{p}<0.05)$ decreased the activities of alanine aminotransferase, aspartate aminotransferase, alkaline phosphatase, gamma glutamyltransferase (Table 3) and bilirubin concentration (Table 5) and increased the concentrations of total protein and albumin in a dose-dependent manner when compared with the untreated group (Table 4). Prevention of liver damage was observed in the groups that received 400 and $600 \mathrm{mgkg}-1 / \mathrm{bw}$ of the extract as well as the silymarin group. Activities of superoxide dismutase and catalase (Table 6) and the concentration of glutathione were significantly $(\mathrm{p}<0.05)$ increased while the concentration of malondialdehyde was significantly $(\mathrm{p}<0.05)$ decreased (Table 7$)$ in the extract and silymarin- pre-treated rats when compared with the untreated group.

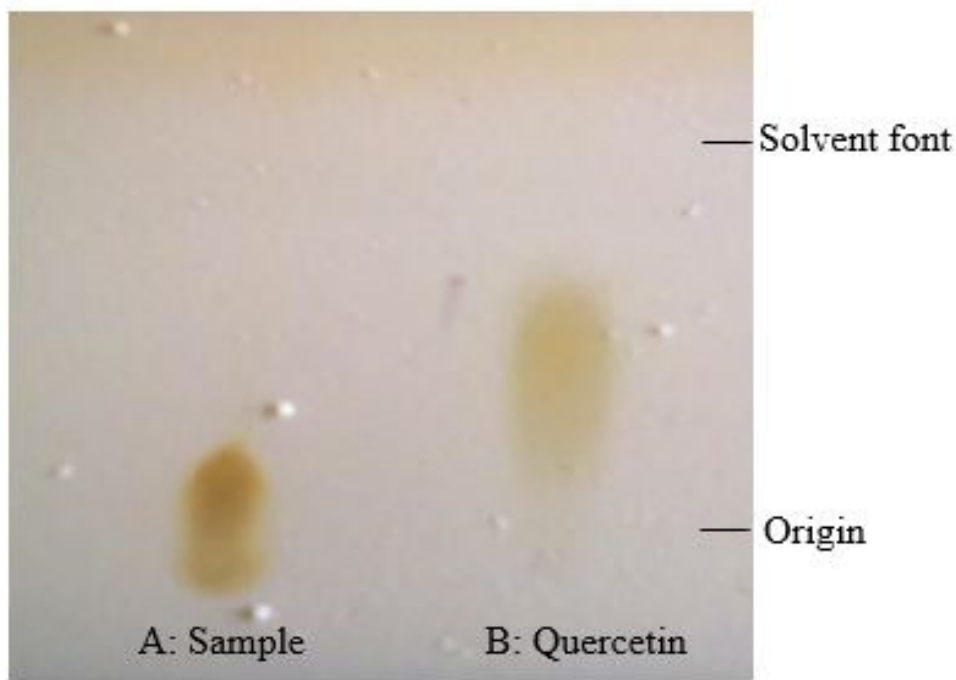

Figure 2. Thin layer chromatogram of ethyl acetate-ethanolicextract fraction of Carica papaya leaves (A) and the standard flavonoid; quercetin (B)

Table 1. Phytochemical constituents of ethyl acetate-ethanolic fraction of Carica papaya leaves

\begin{tabular}{|c|c|c|}
\hline Test & Composition $(\mathrm{mg} / \mathrm{ml}) \times 10^{-2}$ & Percentage composition \\
\hline Flavonoid & $16.8 \pm 0.05$ & 65.63 \\
\hline Phenol & $5.95 \pm 0.15$ & 23.24 \\
\hline Alkaloid & $1.25 \pm 0.15$ & 4.88 \\
\hline Saponin & $0.85 \pm 0.02$ & 3.30 \\
\hline Glycosides & $0.54 \pm 0.01$ & 2.11 \\
\hline Tannins & $0.14 \pm 0.01$ & 0.55 \\
\hline Phlobatannin & $0.07 \pm 0.01$ & 0.27 \\
\hline
\end{tabular}


Table 2. Liver to body weight ratio of acetaminophen-induced rats pre-administered with ethyl acetateethanolic extract fraction of Carica papaya leaves

\begin{tabular}{|c|c|}
\hline Groups & Liver to body weight ratio (\%) \\
\hline Control (non-induced) & $3.22 \pm 0.25^{\mathrm{a}}$ \\
\hline Untreated (Acetaminophen) & $3.29 \pm 0.11^{\mathrm{a}}$ \\
\hline Silymarin + Acetaminophen & $3.62 \pm 0.14^{\mathrm{a}}$ \\
\hline $100 \mathrm{mgkg}^{-1}$ bw extract fraction + Acetaminophen & $3.31 \pm 0.07^{\mathrm{a}}$ \\
\hline $200 \mathrm{mgkg}^{-1}$ bw extract fraction + Acetaminophen & $3.28 \pm 0.09^{\mathrm{a}}$ \\
\hline $400 \mathrm{mgkg}^{-1}$ bw extract fraction + Acetaminophen & $3.58 \pm 0.08^{\mathrm{a}}$ \\
\hline $600 \mathrm{mgkg}^{-1}$ bw extract fraction + Acetaminophen & $3.03 \pm 0.19^{\mathrm{a}}$ \\
\hline Non-induced $+600 \mathrm{mgkg}^{-1}$ bw extract fraction & $3.13 \pm 0.26^{\mathrm{a}}$ \\
\hline
\end{tabular}

Table 3. Specific activities of alanine aminotransferase (ALT), aspartate aminotransferase (AST), alkaline phosphate (ALP) and $\gamma$-glutamyltransferase (GGT) $\left(\right.$ nmolmin $^{-1}$ mgprotein $\left.^{-1}\right)$ in the serum of the rats

\begin{tabular}{|c|c|c|c|c|}
\hline Groups & ALT & AST & ALP & GGT \\
\hline Control (non-induced) & $13.80 \pm 0.06^{\mathrm{a}}$ & $8.73 \pm 0.83^{\mathrm{a}}$ & $11.50 \pm 0.43^{\mathrm{a}}$ & $8.5 \pm 0.15^{\mathrm{a}}$ \\
\hline Acetaminophen-induced & $30.01 \pm 0.20^{\mathrm{e}}$ & $18.87 \pm 0.75^{\mathrm{c}}$ & $24.90 \pm 0.05^{\mathrm{d}}$ & $38.86 \pm 0.15^{\mathrm{f}}$ \\
\hline $\begin{array}{c}\text { Silymarin + Acetaminophen } \\
\begin{array}{c}100 \mathrm{mgkg}^{-1} \text { bw extract fraction + } \\
\text { Acetaminophen }\end{array}\end{array}$ & $15.60 \pm 0.07^{\mathrm{a}}$ & $6.12 \pm 0.35^{\mathrm{a}}$ & $13.90 \pm 0.32^{\mathrm{a}}$ & $14.70 \pm 0.11^{\mathrm{b}}$ \\
\hline $\begin{array}{c}200 \mathrm{mgkg}^{-1} \text { bw extract fraction }+ \\
\text { Acetaminophen }\end{array}$ & $22.98 \pm 0.06^{\mathrm{c}}$ & $6.68 \pm 0.42^{\mathrm{b}}$ & $19.90 \pm 0.22^{\mathrm{c}}$ & $25.55 \pm 0.13^{\mathrm{d}}$ \\
\hline $\begin{array}{c}400 \mathrm{mgkg}^{-1} \text { bw extract fraction }+ \\
\text { Acetaminophen }\end{array}$ & $19.60 \pm 0.03^{\mathrm{b}}$ & $6.26 \pm 0.86^{\mathrm{b}}$ & $17.40 \pm 0.95^{\mathrm{b}}$ & $20.67 \pm 0.17^{\mathrm{c}}$ \\
\hline $\begin{array}{c}600 \mathrm{mgkg}^{-1} \text { bw extract fraction }+ \\
\text { Acetaminophen }\end{array}$ & $18.50 \pm 0.08^{\mathrm{b}}$ & $6.17 \pm 0.46^{\mathrm{b}}$ & $16.91 \pm 0.31^{\mathrm{b}}$ & $18.99 \pm 0.10^{\mathrm{c}}$ \\
\hline $\begin{array}{c}\text { Non-induced + } 600 \text { mgkg } \\
\text { extract fraction }\end{array}$ & $13.12 \pm 0.05^{\mathrm{a}}$ & $8.49 \pm 0.55^{\mathrm{a}}$ & $20.33 \pm 0.07^{\mathrm{a}}$ & $8.23 \pm 0.06^{\mathrm{a}}$ \\
\hline
\end{tabular}

Values are expressed as Mean \pm SEM $(n=4)$. Values along the column with different superscripts are significantly different $(\mathrm{P}<0.05)$

Table 4. Bilirubin concentration $(\mathrm{mg} / / \mathrm{dl})$ in serum of the rats

\begin{tabular}{|c|c|c|}
\hline Groups & Total & Conjugated \\
\hline Control (non-induced) & $3.13 \pm 0.68^{\mathrm{a}}$ & $5.58 \pm 0.56^{\mathrm{a}}$ \\
\hline Acetaminophen-induced & $9.04 \pm 0.27^{\mathrm{c}}$ & $9.49 \pm 0.12^{\mathrm{b}}$ \\
\hline Silymarin + Acetaminophen & $4.28 \pm 0.22^{\mathrm{b}}$ & $7.78 \pm 1.12^{\mathrm{c}}$ \\
\hline $100 \mathrm{mgkg}^{-1}$ bw fraction + Acetaminophen & $8.14 \pm 0.73^{\mathrm{c}}$ & $7.89 \pm 0.50^{\mathrm{c}}$ \\
\hline $200 \mathrm{mgkg}^{-1}$ bw fraction + Acetaminophen & $6.62 \pm 0.27^{\mathrm{c}}$ & $7.45 \pm 0.09^{\mathrm{c}}$ \\
\hline $400 \mathrm{mgkg}^{-1}$ bw fraction + Acetaminophen & $4.62 \pm 0.40^{\mathrm{b}}$ & $7.74 \pm 1.56^{\mathrm{c}}$ \\
\hline $600 \mathrm{mgkg}^{-1}$ bw fraction + Acetaminophen & $4.28 \pm 0.09^{\mathrm{b}}$ & $6.44 \pm 0.68^{\mathrm{c}}$ \\
\hline (Non-induced) + 600 mgkg-1 bw fraction & $7.91 \pm 1.82^{\mathrm{d}}$ & $11.81 \pm 1.47^{\mathrm{d}}$ \\
\hline
\end{tabular}

Values are expressed as Mean \pm SEM $(n=4)$. Values along the column with different superscripts are significantly different $(\mathrm{P}<0.05)$. 
Table 5. Total protein, albumin and globulin concentration $(\mathrm{g} / \mathrm{dl})$ in the serum of the rats

\begin{tabular}{|c|c|c|c|}
\hline Groups & Total protein $(\mathrm{g} / \mathrm{dl})$ & Albumin $(\mathrm{g} / \mathrm{dl})$ & Globulin(g/dl) \\
\hline Control (non-induced) & $13.63 \pm 0.67^{b}$ & $12.85 \pm 0.31^{\mathrm{c}}$ & $0.77 \pm 0.05^{\mathrm{a}}$ \\
\hline Untreated (Acetaminophen) & $8.94 \pm 2.39^{\mathrm{a}}$ & $5.70 \pm 0.40^{\mathrm{a}}$ & $3.22 \pm 0.14^{\mathrm{b}}$ \\
\hline Silymarin + Acetaminophen & $13.19 \pm 1.99^{\mathrm{b}}$ & $12.39 \pm 0.6^{c}$ & $0.66 \pm 0.08^{\mathrm{a}}$ \\
\hline $\begin{array}{c}100 \mathrm{mgkg}^{-1} \text { bw fraction }+ \\
\text { Acetaminophen }\end{array}$ & $10.76 \pm 0.85^{\mathrm{a}}$ & $9.84 \pm 1.45^{\mathrm{b}}$ & $0.92 \pm 0.08^{a}$ \\
\hline $\begin{array}{l}200 \mathrm{mgkg}^{-1} \text { bw fraction }+ \\
\text { Acetaminophen }\end{array}$ & $11.94 \pm 2.38^{\mathrm{ab}}$ & $11.10 \pm 0.88^{\mathrm{bc}}$ & $0.82 \pm 0.02^{a}$ \\
\hline $\begin{array}{l}400 \mathrm{mgkg}^{-1} \text { bw fraction }+ \\
\text { Acetaminophen }\end{array}$ & $12.53 \pm 2.45^{\mathrm{ab}}$ & $11.81 \pm 1.43^{\mathrm{bc}}$ & $0.72 \pm 0.09^{\mathrm{a}}$ \\
\hline $\begin{array}{c}600 \mathrm{mgkg}^{-1} \mathrm{bw} \text { fraction }+ \\
\text { Acetaminophen }\end{array}$ & $12.79 \pm 1.31^{\mathrm{b}}$ & $12.07 \pm 1.71^{\mathrm{c}}$ & $0.68 \pm 0.15^{\mathrm{a}}$ \\
\hline $\begin{array}{c}\text { Non-induced }+600 \mathrm{mgkg}^{-1} \mathrm{bw} \\
\text { fraction }\end{array}$ & $15.22 \pm 1.23^{\mathrm{bc}}$ & $14.65 \pm 0.70^{\mathrm{d}}$ & $0.69 \pm 0.11^{a}$ \\
\hline
\end{tabular}

Values are expressed as Mean \pm SEM $(n=4)$. Values along the column with different superscripts are significantly different $(\mathrm{P}<0.05)$.

Table 6. Specific activities of superoxide dismutase (SOD) and catalase (CAT) $\left(\right.$ nmolmin $\left.^{-1} \mathrm{mg}_{\text {protein }}{ }^{-1}\right)$ in liver of the rats

\begin{tabular}{|c|c|c|}
\hline Groups & SOD & Catalase \\
\hline Control (non-induced) & $0.31 \pm 0.07^{\mathrm{d}}$ & $3.07 \pm 0.01^{\mathrm{d}}$ \\
\hline Acetaminophen-induced & $0.19 \pm 0.0^{\mathrm{a}}$ & $0.79 \pm 0.07^{\mathrm{a}}$ \\
\hline Silymarin + Acetaminophen & $0.29 \pm 0.06^{\mathrm{c}}$ & $2.78 \pm 0.05^{\mathrm{c}}$ \\
\hline $100 \mathrm{mgkg}^{-1}$ bw fraction + Acetaminophen & $0.20 \pm 0.09^{\mathrm{b}}$ & $2.14 \pm 0.05^{\mathrm{b}}$ \\
\hline $200 \mathrm{mgkg}^{-1}$ bw fraction + Acetaminophen & $0.21 \pm 0.08^{\mathrm{b}}$ & $2.22 \pm 0.02^{\mathrm{b}}$ \\
\hline $400 \mathrm{mgkg}^{-1}$ bw fraction + Acetaminophen & $0.24 \pm 0.09^{\mathrm{b}}$ & $2.59 \pm 0.01^{\mathrm{c}}$ \\
\hline $600 \mathrm{mgkg}^{-1}$ bw fraction + Acetaminophen & $0.28 \pm 0.09^{\mathrm{c}}$ & $2.70 \pm 0.01^{\mathrm{c}}$ \\
\hline Non-induced + 600 mgkg bw fraction & $0.31 \pm 0.02^{\mathrm{d}}$ & $3.14 \pm 0.01^{\mathrm{d}}$ \\
\hline
\end{tabular}

Values are expressed as Mean \pm SEM $(n=4)$. Values along the column with different superscripts are significantly different $(\mathrm{P}<0.05)$.

Table 7. Levels of reduced glutathione ( $\mathrm{nmol} / \mathrm{mmg}$ protein) and malondialdehyde ( $\mathrm{mmol} / \mathrm{mg}$ protein) liver of the rats

\begin{tabular}{|c|c|c|}
\hline Groups & Red Glutathione & $\operatorname{MDA}\left(\times 10^{-4}\right)$ \\
\hline Control (non-induced) & $2.68 \pm 0.02^{\mathrm{d}}$ & $1.03 \pm 0.04^{\mathrm{a}}$ \\
\hline Acetaminophen-induced & $0.86 \pm 0.01^{\mathrm{a}}$ & $2.49 \pm 0.01^{\mathrm{d}}$ \\
\hline Silymarin + Acetaminophen & $1.59 \pm 0.06^{\mathrm{c}}$ & $1.18 \pm 0.07^{\mathrm{b}}$ \\
\hline $\begin{array}{c}100 \mathrm{mgkg}^{-1} \text { bw fraction }+ \\
\text { Acetaminophen }\end{array}$ & $1.18 \pm 0.03^{\mathrm{b}}$ & $1.36 \pm 0.02^{\mathrm{c}}$ \\
\hline $\begin{array}{c}200 \mathrm{mgkg}^{-1} \text { bw fraction }+ \\
\text { Acetaminophen }\end{array}$ & $1.23 \pm 0.03^{b}$ & $1.32 \pm 0.01^{\mathrm{c}}$ \\
\hline $\begin{array}{c}400 \mathrm{mgkg}^{-1} \text { bw fraction }+ \\
\text { Acetaminophen }\end{array}$ & $1.57 \pm 0.01^{\mathrm{c}}$ & $1.19 \pm 0.06^{\mathrm{b}}$ \\
\hline $\begin{array}{c}600 \mathrm{mgkg}^{-1} \text { bw fraction }+ \\
\text { Acetaminophen }\end{array}$ & $1.68 \pm 0.08^{\mathrm{c}}$ & $1.18 \pm 0.01^{\mathrm{b}}$ \\
\hline Non-induced $+600 \mathrm{mgkg}^{-1}$ bw fraction & $3.59 \pm 0.01^{\mathrm{e}}$ & $1.02 \pm 0.01^{\mathrm{a}}$ \\
\hline
\end{tabular}

Values are expressed as Mean \pm SEM $(n=4)$. Values along the column with different superscripts are significantly different $(\mathrm{P}<0.05)$. 


\section{Discussion}

Crude flavonoid rich fractions (about 65\%) were obtained from the leaves of $C$. papaya using ethyl acetate and ethanol. This may be due to the ability of both solvents to fraction polar phytochemicals. Flavonoids, phenols and saponin as also reported by Adeneye and Olagunju (2009) possess antioxidant activities in the aqueous seed extract of $C$. papaya leaves.

Data obtained suggest that there may be neither inflammation nor constriction of the tissue since liverbody weight ratio was not altered by the pre-administration of the fraction to acetaminophen-induced rats. The toxic effect of acetaminophen caused peroxidative degradation in the adipose tissue resulting in fatty infiltration and degeneration of the hepatocytes (Wankhade et al., 2011). The pre-administration of the experimental animals with fraction produced little or no degeneration of hepatocytes.

There is increase in the activities of alanine aminotransferase (ALT) and aspartate aminotransferase (AST) in the acetaminophen-induced group hepatocyte damage though ALT is a more sensitive marker for liver damage than AST (Ojiako and Nwanjo, 2006).

Liver function tests are parameters that give information about the state of liver since most liver diseases present mild symptoms initially hence it is vital that these diseases be detected early. The protective effect of the fraction against acetaminophen-induced liver marker enzymes (such as ALT, AST, ALP and GGT) alterations in this study may be due to the formation of the reactive intermediate NAPQI that covalently binds to protein and DNA. The increase in these parameters was prevented by the EEFCPL in a dose dependent manner which indicates that its protective potential may be due to the presence of flavonoids that acts as antioxidant.

Albumin is the protein made specifically by the liver. It is the main constituent of total protein. A reduction in the total protein and albumin concentration indicates acute or chronic liver damage which may be due to the impairment in liver biosynthetic ability (Singh et al., 2011). From this study, pre-administration of EEFCPL prevented decrease in liver and serum albumin and total protein concentration in the acetaminophen-induced rats. Previous study shows that hepatoprotective plant maintains these concentrations near normal (Adeneye et al., 2009). Globulin is the remaining fraction of total protein when albumin is removed. It is a marker for immunogenic response. During diseased condition, the level is usually increased in order to respond to the assault caused in the body. An elevation in globulin concentration of acetaminopheninduced rats may be immunogenic response. An observed reduction in the group pre-administered with EEFCPL was about $15 \%$.

The increased concentration in the total and conjugated bilirubin in the serum indicates bilirubinaemia. The ethyl acetate-ethanolic fraction of Carica papaya leaves was able to protect the serum from producing excessive bilirubin and maintain its concentration in the liver as previously reported in a study by Wankhade (2011). An elevated serum conjugated bilirubin concentration in the control group administered with EEFCPL ( $\left.600 \mathrm{mgkg}^{-1} \mathrm{bw}\right)$ may be as a result of the increase in the clearance of bilirubin by the liver.

In this study, the reduction in the superoxide dismutase (SOD) activity in the acetaminophen-induced rats was as a result of elevated superoxide anion and decreased nitric oxide levels which can also results to loss of membrane integrity and. Pre-administration of EEFCPL was able to increase the activity of SOD in order to counteract the effect caused by acetaminophen in a dose-dependent fashion with the highest dose activity similar to silymarin.

Superoxide Dismutase (SOD) catalyzes the dismutation of superoxide anion radicals to hydrogen peroxide. SOD is a chain breaking antioxidant that protect against deleterious effects of lipid peroxidation (Saravanan et al., 2003). Catalase (CAT) is an enzyme that degrades hydrogen peroxide to molecular oxygen and water. It plays and important role in the acquisition of tolerance to oxidative stress and in adaptive cellular response (Sankaran et al., 2010). The lowered activity of SOD in the liver of acetaminophen-induced rats indicates the presence of hydrogen peroxide radicals which was prevented in the liver of rats pre-administered 
with the EEFCPL. Catalase and SOD activities in the groups pre-administered with 400 and $600 \mathrm{mgkg}^{-1} \mathrm{bw}$ are similar to silymarin pre-administered group.

The decreased level in reduced glutathione (GSH) in the acetaminophen-induced group indicates the exhaustion of the GSH in circulation which may lead to intracellular generation of reactive oxygen species (ROS). The fraction counteracts the damaging effect of the ROS generated by acetaminophen. EEFCPL doses at 400 and $600 \mathrm{mgkg}^{-1} \mathrm{bw}$ weight increased the activity of GSH. An elevated concentration in the control group that received $600 \mathrm{mgkg}^{-1}$ bw of the fraction to about $35 \%$ when compared to the normal range in rats may be as a result of the bioavailability of the fraction thus enhancing the detoxification of reactive metabolites by conjugation process.

The non-enzymatic antioxidant system complements the activity of the enzymatic antioxidants system in preventing cells form excessive oxidative stress by acting as free radical scavengers (Ajiboye et al., 2010). Analgesics such as acetaminophen have previously been reported to decrease antioxidant enzymes (such as SOD and CAT) and the non-antioxidant enzyme (GSH) activities in rat (Halici et al., 2005).

Pre-administration of EEFCPL protected the liver against elevated malondialdehyde (MDA) concentration in acetaminophen-induced rats. Pre-administration with EEFCPL at 400 and $600 \mathrm{mgkg}^{-1} \mathrm{bw}$ brought the MDA concentration to be about the same value as that of silymarin pre-administered rats. The observed similarity in the concentrations of the normal control group and toxicity control group that received $600 \mathrm{mgkg}^{-1} \mathrm{bw}$ may be attributed to the prevention of generation of lipid peroxidation products. MDA is a lipid peroxidation product that causes cellular damage by reacting with lipids causing peroxidation and release

of products including hydrogen peroxide. An increase in lipid peroxides indicates serious damage to cell membranes, inhibition of several important enzymes, reduced cellular function and cell death (Usunobun et al., 2012).

\section{Conclusions}

The protective effect observed in the rats pre-administered with EEFCPL may be attributed to the fraction ability to decrease the effect of the metabolic activation of acetaminophen or by acting as an antioxidant for scavenging free radicals. Activities of the Carica papaya ethyl acetate-ethanol fraction may be mediated by their flavonoids or alkaloids components or by their combination via antioxidant and free radicals scavenging activities.

\section{Authors' Contributions}

Prof HOB Oloyede-Conceptualisation, interpretation of data, approval of draft manuscript; HY Lukman- Experimentation, Preparation of draft manuscript; MO Salawu- Conceptualisation, Interpretation of data, Preparation of draft manuscript. All authors read and approved the final manuscript.

\section{Ethical approval}

This research was approved by the Faculty of Life Sciences, University of Ilorin, Ethical Review Committee, being in conformity with the norms of researches involving animals or humans. 
Oloyede HOB et al. (2020). Not Sci Biol 12(3):556-567

\section{Acknowledgements}

This research received no specific grant from any funding agency in the public, commercial, or not-forprofit sectors.

\section{Conflict of Interests}

The authors declare that there are no conflicts of interest related to this article.

\section{References}

Adeneye AA, Olagunju JA, Banjo AAF, Abdul SF, Sanusi OA, Sanni OO, ... Shonoiki OE (2009). The aqueous seed extract of Carica papaya Linn. Prevents carbon tetrachloride induced hepatotoxicity in rats. International Journal of Applied Research in Natural Products 2(2):19-32. https://doi.org/10.1.1.895.5985

Adeneye AA, Olagunju JA (2009). Preliminary hypoglycemic and hypolipidemic activities of the aqueous seed extract of Carica papaya Linn. In Wistar rats. Biology and Medicine 1(1):1-10. https://doi.org/10.1002/(SICI)109915739199606)10:4<327

Ajiboye TO, Salau AK, Yakubu MT, Oladiji AT, Akanji MA, Okogun JI (2010). Acetaminophen perturbed redox homeostasis in Wistar rat liver: protective role of aqueous Pterocarpus osun leaf extract. Drug and Chemical Toxicology 33(1):77-87. https://doi.org/10.3109/01480540903170746

Ali M, Qadir MI, Saleem M, Janbaz KH, Gul H, Hussain L, Ahmad B (2013). Hepatoprotective potential of Convolvulus arvensis against paracetamol-induced hepatotoxicity. Bangladesh Journal of Pharmacology 8(3):300-304. https://doi.org/10.3329/bjp.v8i3.15165

Albalawi MA, Albalawi SA, Albalawi THS, Almuhawwis KS, Alswilem AM, Aldakhil FM, ... Alharith MS (2019). Evaluation of recent updates regarding acetaminophen-induced acute liver failure. Archives of Pharmacy Practice $1: 56$.

Cai W, Gu X, Tang J (2010). Extraction, purification, and characterization of the flavonoids from Opuntia milpa alta skin. Czech Journal of Food Sciences 28:108-116. https://doi.org/10.17221/122/2009-CJFS

Chavan TC, Kuvalekar AA (2019). A review on drug induced hepatotoxicity and alternative therapies. Journal of Nutrition Health Food Sciences 7(3):1-29. https://doi.org/10.15226/jnhfs.2019.001160

Ellman GL (1959). Tissue sulfhydryl groups. Archive of Biochemistry and Biophysics 82(1):70-77. https://doi.org/10.1016/0003-9861(59)90090-6

Gornall AG, Bardawill CJ, David M (1949). Determination of serum proteins by means of the biuret reaction. Journal of Biological Chemistry 177:751-766.

Grant GH Sliverman LM, Christenson RH (1987). Amino acids and proteins; fundamentals of clinical chemistry. Tietz, N.W. Editor, 3rd edition, W.B. Saunders Company Philadelphia, USA, pp 328-329.

Halici M, Odabasoglu F, Suleyman H, Cakir A, Aslan A, Bayir Y (2005). Effects of water fraction of Usnea longissima on antioxidant enzyme activity and mucosal damage caused by indomethacin in rats. Phytomedicine 12(9):656-662. https://doi.org/10.1016/j.phymed.2004.06.021

Harborne JB (1973). Phytochemical methods: a guide to modern techniques of plant analysis. 2nd edition, Chapman A \& Hall, London pp 279.

Liu RH (2004). Potential synergy of photochemicals in cancer prevention; mechanism of action. The Journal of Nutrition 134(12):3479-3485. https://doi.org/10.1093/jn/134.12.3479S

Mabry TJ, Harborne JB, Mabry H (1975). Isolation and purification of flavonoids. Eds., Academic Press, New York.

Markham K (1989). Isolation technology for flavonoids in the flavonoids. In: Harborne JB, Mabry TJ, Mabry H (Eds). Academic Press, New York.

Mistra HP, Fridovich I (1972). The role of superoxide anion in the autooxidation of epinephrine and simple assay for superoxide dismutase. Journal of Biological Chemistry 247(10):3170-3175.

Odebiyi A, Sofowora AE (1978). Phytochemical screening of Nigeria medical plants. Part III. Lioydia 41:234-246. https://doi.org/10.4236/abc.2013.36059 
Ojiako OA, Nwanjo HU (2006). Is Vernonia amygdalina hepatotoxic or hepatoprotective? Response from biochemical and toxicity studies in rats. African Journal of Biotechnology 5(18):1648-1651. https://doi.org/10.5897/ajb06.206

Oloyede HOB, Adaja MC, Ajiboye TO, Salawu MO (2015). Anti-ulcerogenic activity of aqueous extract of Carica papaya seed on indomethacin-induced peptic ulcer in male albino rats. Journal of Integrative Medicine 13(2):105-114. https://doi.org/10.1016/S2095-4964(15)60160-1

Otsuki N, Dang N, Kumagai E, Kondo A (2009). Aqueous extract of Carica papaya leaves exhibits anti-tumor activity and immunomodulatory effects. Journal of Ethnopharmacology 127:760-767. https://doi.org/10.1016/j.jep.2009.11.024

Owoyele BV, Olubori MA, Adeoye AF, Soladoye AO (2008). Anti-inflammatory activities of ethanolic fraction of Carica papaya leaves. Inflammopharmacology 16:168-173. https://doi.org/10.1007/s10787-008-7008-0

Ozougwu JC (2017). Physiology of the liver. International Journal of Research in Pharmacy and Biosciences 4(8):13-24.

Rec GC (1972). Activity of alkaline phosphatase. Journal of Clinical Chemistry and Clinical Biochemistry 10:182.

Reitman S, Frankel S (1957). A colorimetric method for determination of serum glutamate-oxaloacetate and pyruvate transaminase. American Journal of Clinical Pathology 28:56-63. https://doi.org/10.1093/ajcp/28.1.56

Saleem M, Naseer F (2014). Medicinal plants in the protection and treatment of liver diseases. Bangladesh Journal of Pharmacology 9:511-526. https://doi.org/10.3329/bjp.v9i4.20648

Sankaran M, Vadivel A, Thangam A (2010). Curative effect of garlic on alcoholic liver disease patients. Jordan Journal of Biological Sciences 3(4):147-152.

Saravanan R, Rajendra N, Prasad NR, Pugalendi KV (2003). Effect of piper beetle leaf fraction on alcohol toxicity in the rat brain. Journal of Medicinal Food 6(3):261-265. https://doi.org/10.1089/10966200360716689

Singh A, Bhat TK, Sharma OP (2011). Clinical biochemistry of hepatotoxicity. Journal of Clinical Toxicology S:4. https://doi.org/10.4172/2161-0495.S4

Sinha A (1972). Colorimetric assay of catalase. Analytic Biochemistry 47(2):389-394. https://doi.org/10.1016/00032697(72)90132-7

Sofowora A (1993). Medicinal plants and traditional medicines in Africa, 2nd edition. Spectrum Books Limited, Sunshine House, Ibadan, Nigeria, pp 191-289.

Thompson M, Jaiswal Y, Wang I, Williams L (2017). Hepatotoxicity: treatment, causes and applications of medicinal plants as therapeutic agents. Journal of Phytopharmacology 6(2):186-193.

Tietz NW (1986). Textbook of clinical chemistry. WB Saunderes, Ed 3, Philadelphia. https://doi.org/10.1016/03074412(86)90182-2

Trease GE, Evans WC (1989). A text-book of pharmacognosy. Bailliere Tindall Ltd, London pp 53. https://doi.org/10.1016/S0140-6736(05)65693-0

Usunobun U, Adegbegi JA, Okugbo TO, Evuen U, Osibemhe M, Okolie NP (2012). N-nitrosodimethylamine (NDMA), liver function enzymes, renal function parameters and oxidative stress parameters: a review. British Journal of Pharmacology and Toxicology 3(4):165-176. https://doi.org/197.210.227.26

Yakubu MT, Nafiu MO, Akanji MA (2006). Effect of aqueous extract of Cochlospermum planchoni rhizome on some kidney and liver functional indices of albino rats. African Journal of Traditional Complementary and Alternative Medicines 8(1):22-26. https://doi.org/4/ajtcam.v8il.60488

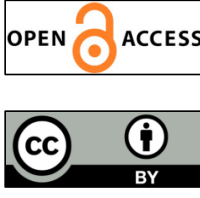

The journal offers free, immediate, and unrestricted access to peer-reviewed research and scholarly work. Users are allowed to read, download, copy, distribute, print, search, or link to the full texts of the articles, or use them for any other lawful purpose, without asking prior permission from the publisher or the author.

License - Articles published in Notulae Scientia Biologicae are Open-Access, distributed under the terms and conditions of the Creative Commons Attribution (CC BY 4.0) License.

(c) Articles by the authors; UASVM, Cluj-Napoca, Romania. The journal allows the author(s) to hold the copyright/to retain publishing rights without restriction. 